\title{
Effect of different treatments of ethrel on ripening behaviour and post- harvest quality of mango (Mangifera indica $L$.) during storage
}

\author{
Sukhjit Kaur \\ Punjab Agricultural University, Regional Research Station, Gurdaspur -143521 (Punjab), INDIA \\ E-mail: sukhi.rose@gmail.com
}

Received: July 25, 2016; Revised received: October 23, 2016; Accepted: January 10, 2017

\begin{abstract}
An experiment was done to assess the effect of various post harvest treatments of ethrel on ripening behaviour and post harvest quality of mango cv. Amrapali (Mangifera indica L.) during storage at Punjab Agricultural University, Regional Research Station, Gurdaspur during the years 2013-14 and 2014-15. The experiment was planned under completely randomized design (CRD) with three replications. The treatment units was six fruits per replication. Total five treatments and control were applied. The objective of this work was to evaluate the effects of various concentrations of ethrel (500 ppm, 750 ppm, 1000 ppm,1250 ppm, 1500 ppm and control ) on shelf life of mango fruits when stored under ambient conditions. The treated fruits were assessed for physiological changes fruit colour, flavour/aroma, organoleptic taste, marketability, ripening, specific gravity, moisture loss, decay, physiological loss in weight (PLW), total soluble solids (TSS), acidity and sugars. The observations were recorded at 5,8 and 11 days after storage. At $11^{\text {th }}$ day of storage these mangoes exhibited deep yellow fruit colour with excellent flavour, organoleptic taste and highly acceptable marketability at $1000 \mathrm{ppm}$ ethrel treatment as compared to other ethrel doses. Fruit ripening $(100 \%)$, specific gravity $(0.84)$, $\operatorname{TSS}\left(23^{\circ}\right.$ Brix $)$ and sugars $(20.65 \%)$ were highest in the fruits treated with $1000 \mathrm{ppm}$ ethrel as compared to rest of treatments at $11^{\text {th }}$ day of storage. Lowest moisture loss $(8.5 \%)$, decay $(1 \%), \operatorname{PLW}(12.50 \%)$ and acidity $(0.12 \%)$ were observed in the fruits treated with $1000 \mathrm{ppm}$ of ethrel as compared to rest of treatments at $11^{\text {th }}$ day of storage. The beneficial effect of the present study is to overcome the problem of uneven and late ripening of Amrapali mango by postharvest treatment of ethrel at $1000 \mathrm{ppm}$ at their mature green stage to develop typical fruit flavour with excellent fruit quality.
\end{abstract}

Keywords: Ethrel, Mango, Post-harvest quality, Ripening behaviour, Storage

\section{INTRODUCTION}

Mango (Mangifera indica L.) is a "National fruit of India" because of its delicious taste, excellent flavor/ aroma, attractive colour, a amount of vitamin A and C. It is most popular fruit among millions of people in India, where it is considered to be the choicest of all indigenous fruits. Mango is grown in an area of 2516.0 thousand hectares with production of 18431.3 thousand metric tonnes (Anonymous, 2014).

Mango has rich diversity in cultivated varieties and out of these, Amrapali is a well known regular bearing dwarf hybrid, fruit is oblong and oblique in shape. The pulp percentage is not so high, excellent in taste, good for table purpose and has better keeping quality at room temperature approximately one week (Chattopadhaya, 1996). The flesh of Amrapali is deep red in colour which may be used for preparing colourful mango nectar and juice. Due to dwarfness of cultivar, it is recommended for kitchen garden and high density planting. The fruit of Amrapali are rich source of $\beta$ carotenoids than its parents i.e. Dashehari and Neelum (Sharma et al., 1981).Fruit maturity at harvest is one of the critical factors affecting the ripening process, quality of ripe fruit including characteristic flavour and taste development in fruit and also determines its post harvest utilization (Lalel et al., 2003). Mangoes in general and are harvested at the mature green pre-climacteric stage and ripened with or without an exogenous application of ethylene. Generally, harvesting at mature and unripe stage improves the storability and transportability, while fruits harvested at ripe stage have an extremely shorter storage life and with less characteristic flavour. On the other hand, fruit harvested at an immature stage will not develop typical fruit flavour and quality is, therefore, strongly impaired (Brackmann et al., 1993).

The need for alternative methods of regulating ripening and senescence is of the utmost importance in conservation and maintenance of quality of mango fruit. Therefore, these days artificial fruit ripening has become a common practice. Mango fruits ripen unevenly on the tree and the natural ripening process can be very slow and unpredictable. To overcome this problem, fruits can be ripened artificially by exposing the fruits to certain chemicals, which initiate the ripening process. Ethephon/ethrel is an ethylene-releasing chemical, which can be used to improve fruit colour development and stimulates ripening process of the 
fruit. Ethrel (2-Chloroethyl phosphonic acid) is well known for induction of early and uniform ripening in a number of fruits including Amrapali mango which harvested unripe, at least commercially and post harvest changes include, acceptability, softening, sweetening and colour changes which associate with ripeness. Calcium carbide treatments are extremely dangerous as commercial calcium carbide contains impurities of arsenic and phosphorushydride, which are toxic to human health. Acetylene is generated from calcium carbide by the addition of water or by contact with moisture in air and act on fruits causing them to ripen in a similar manner to ethylene. The benefits of ethylene induced ripening were recently reported for 'Ataulfo' Mangoes (Montalvo et al., 2007). The rate of ripening in mangoes can accelerated by treating the fruit with ethylene (Kader and Mitcham, 2008).

Mango is a climacteric fruit with short shelf life. When mango fruits ripen, they become softy and deteriorate in short time. As the matter of this, it is difficult to deliver ripened mango to larger market in big cities and hence, reduces the chance for better profit to farmers. Meanwhile, green mature mango is firm enough and can maintain its appearance during transportation and ethrel application can hasten fruit ripening. This brings more advantages to distribute to distant market places. The role of ethylene in the regulation of fruit ripening in many kinds of fruits was investigated. Montalvo et al. (2007) concluded that ripening reactions controlled by ethylene can be increased by exposure of the fruit to an atmosphere containing exogenous ethylene in order to produce homogeneous external colour. Ethrel (2, chloroethyl phosphonic acid) is one of the ethylene releasing substances, known mainly for its ability to induce fruit ripening. Aqueous solution of ethrel is stable below $\mathrm{pH}$ 3.5. Above $\mathrm{pH} 3.5$, the hydrolysis of ethrel begins with the release of free ethylene along with chloride and phosphate ions. On dipping the mature fruits in ethrel, it enters into the fruit cells, releases ethylene and hastens the ripening process. Ethrel has been found very effective growth regulator in ripening and improving fruit quality in many climacteric fruits such as guava (Mohamed Nour and Abu Goukh, 2010) mango (Singh et al., 2012) and banana (Venkatasubbaiah et al., 2013). Ripening is promoted in many harvested fruits by dipping in 500 to $2000 \mathrm{ppm}$ ethrel in aqueous solution (Mohamed and Abu-Goukh, 2003).

Keeping in view the usefulness of ethrel treatments in fruits as revealed by various scientists, the present study was aimed to evaluate the effectiveness of postharvest immersion in different ethrel concentrations on the postharvest quality attributes of mango cultivar Amrapali (Mangifera indica L.) fruits kept at ambient temperature.

\section{MATERIALS AND METHODS}

The present investigation was carried out at PAU,
Regional Research Station, Gurdaspur during the years 2013-14 and 2014-15.This station is situated between $32^{\circ} 02^{\prime} \mathrm{N}$ Latitude, $75^{\circ} 22^{\prime} \mathrm{E}$ Longitude and has an altitude of about $265.17 \mathrm{~m}$ from mean sea level. The total six treatments of ethrel along with control were applied to assess the ripening behaviour and post-harvest quality of mango (Mangifera indica L.) during storage at room temperature.

The fruits of mango cv. Amrapali which were physiologically mature and have attained full size were used for study. The fruits were selected on the basis of uniformity, maturity, size and shape. The experiment was laid out under completely randomized block design (CRD) with three replications. The treatment unit was six fruits per replication. The fruits were washed with clean water, dipped for 30seconds in $0.01 \%$ Bavistin and dried with muslin cloth before use. The fruits were dipped for five minutes in the following concentrations of ethrel solution i.e. $250 \mathrm{ppm}, 500 \mathrm{ppm}$, 750ppm, 1000ppm, 1250ppm and control. After each treatment, the fruits were air dried at ambient temperature for 30 minutes in an attempt to reduce possible chemical injury. The treated fruits were wrapped in butter paper and packed in light weighed corrugated card board box for ripening purposes at ambient storage conditions. Data were recorded after 5, 8 and 11 days of storage. During the experimentation, average maximum and minimum room temperature was 32.8 and 24.75 respectively with average relative humidity $85.05 \%$. Mature fruits of Amrapali according to maturity indices were harvested in July at specific gravity of 1.00 and immediately brought to laboratory for further study.

Physical qualitative characters i.e. fruit skin colour (surface colour of ripened fruit was recorded visually at ripening stage matching with the Royal Horticultural Society colour chart), flavour and aroma, organoleptic taste, and marketability were recorded with opinion of panel of 5 judges who scored according to hedonic scale suggested by Amerine et al. (1965). Fruit ripening $(\%)$, specific gravity, moisture $\operatorname{loss}(\%)$, decay $(\%)$, $\operatorname{PLW}(\%)$, fruit firmness $(\mathrm{lb}), \mathrm{TSS}\left({ }^{\circ} \mathrm{brix}\right)$, acidity $(\%)$ and sugar percentage were also recorded by using standard analytical methods. Statistical analyses were carried out as suggested by Gomez and Gomez (1984).

\section{RESULTS AND DISCUSSION}

Effect on colour development: Present investigation (Table 1) revealed that ethrel application had significantly influenced the sensory evaluation scores for flesh colour, flavour/ aroma and overall acceptability scores. Out of all the concentrations of ethrel tried, 250 - 1000 ppm gave the most attractive and deep coloured fruits. Data presented in Table 1 shows that with increase in ethrel concentration from $250 \mathrm{ppm}$ up to $1000 \mathrm{ppm}$, there was significant change in skin colour i.e. greenish yellow to deep yellow on $5-11^{\text {th }}$ day, while yellow colour was recorded on $8^{\text {th }}-11^{\text {th }}$ day of 


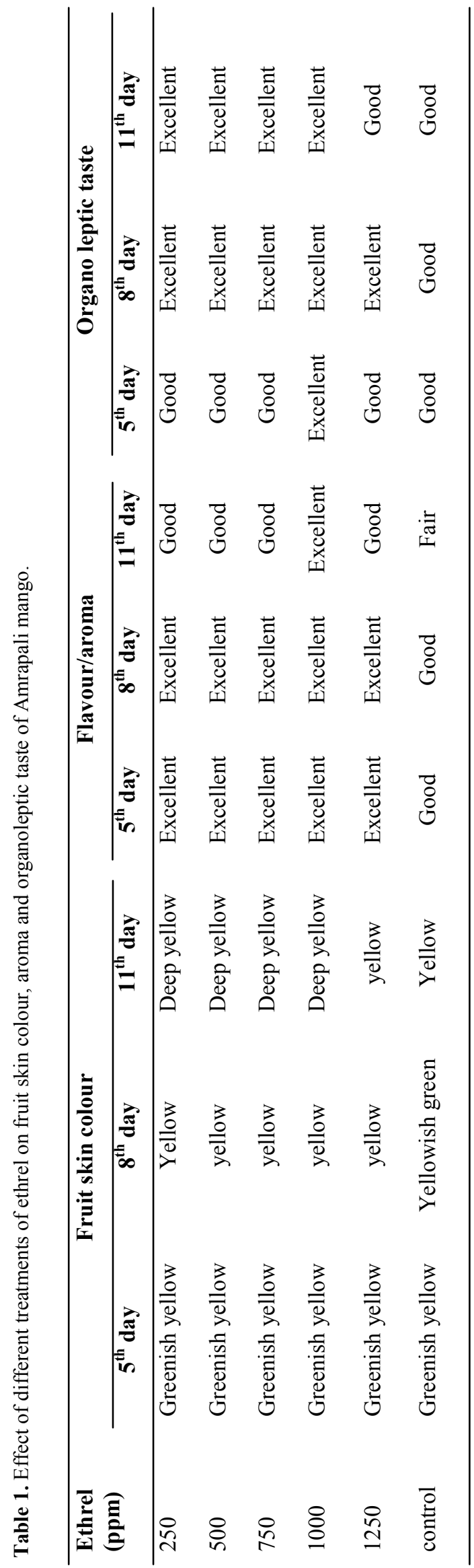

storage with $1250 \mathrm{ppm}$ ethrel. While in control, yellowish green to yellow colour is noticed from $5-11^{\text {th }}$ day of storage. The colour development was better due to rapid degradation of chlorophyll and higher synthesis of carotenoids and other pigments in applied treatments. The findings of the present study confirm with the findings of Singh and Janes (2001) and Singh et al. (2012) in mango. The change in colour during ripening may be due to the synthesis of mainly carotenoids accompanied by the simultaneous loss of chlorophyll (Reyes and Paul,1995). Exposures of fruits to gas ethylene or ethephon solution have been reported to improve their colour and quality during storage and marketing (Kulkarni et al., 2004).

The findings of Dhillon and Mahajan (2011) in pear, Singh et al.(2012) in mango and Singh et al. (2012) in papaya support the contention that ethrel treated fruits develop attractive and deep coloured fruits. However, the specific mode of action of ethrel in accelerating colour development is not clearly under stood. Mohamed Nour and Abu Goukh (2010) observed that peel colour score progressively increased during ripening of guava fruits. They observed that fruits treated with ethrel (250-1000 ppm) reached the full yellow stage at 3, 4 and 6 days earlier than untreated fruits respectively. They also reported ethrel treated fruits had reached the soft stage 2-6 days earlier than the control. Similarly Mahajan et al. (2010) reported that the banana fruits treated with ethylene gas or ethephon solution recorded significant improvement in yellow colour of the peel as compared to untreated control. Ethylene gas and ethephon are treatment are known to accelerate the chlorophyll degradation and induce yellowness in green tissues of many fruits (Mahajan et al., 2008).

Effect on flavour/aroma, organoleptic taste and marketability: The excellent flavour and aroma of fruits were observed with the fruits treated with ethrel 200 and $750 \mathrm{ppm}$ on $5^{\text {th }}, 8^{\text {th }}$ day of storage, while ethrel $1000 \mathrm{ppm}$ gave excellent flavour only upto $11^{\text {th }}$ day of storage. But after $1000 \mathrm{ppm}$ treatment, it was found to be good at $11^{\text {th }}$ day of storage. While in control it was good to fair at $11^{\text {th }}$ day of storage (Table1). The present findings are also reported earlier in guava by Hiwale and Singh (2003). The organoleptic taste was good to excellent from 5-11 ${ }^{\text {th }}$ day of storage but it was excellent at $11^{\text {th }}$ day of storage. It was good at $11^{\text {th }}$ day of storage at $1250 \mathrm{ppm}$ and control treatment. Similar observations were observed by Singh et al. (2012) in mango and Dhillon and Mahajan (2011) in pear. Das et al. $(2011,2013)$ also reported that ethrel induces good flavour in mango The improvement in sensory quality with ethylene gas or ethephon treatments may be due to the role of ethylene / ethephon in promoting changes which are important to flavour quality and formation of aroma volatile in climacteric fruit (Kulkarni et al., 2004).

Change in flavor and taste may be due to the ripening 
Sukhjit Kaur / J. Appl. \& Nat. Sci. 9 (1): 85 - 93 (2017)

Table 2. Effect of different treatments of ethrel on marketability, ripening and specific gravity of Amrapali mango.

\begin{tabular}{|c|c|c|c|c|c|c|c|c|c|}
\hline \multirow{2}{*}{$\begin{array}{l}\text { Ethrel } \\
\text { (ppm) }\end{array}$} & \multicolumn{3}{|c|}{ Marketability } & \multicolumn{3}{|c|}{ Ripening (\%) } & \multicolumn{3}{|c|}{ Specific gravity } \\
\hline & $5^{\text {th }}$ day & $8^{\text {th }}$ day & $11^{\text {th }}$ day & $5^{\text {th }}$ day & $8^{\text {th }}$ day & $11^{\text {th }}$ day & $\overline{5^{\text {th }} \text { day }}$ & $8^{\text {th }}$ day & $\overline{11^{\text {th }} \text { day }}$ \\
\hline 250 & $\begin{array}{c}\text { Highly } \\
\text { Acceptable }\end{array}$ & $\begin{array}{c}\text { Highly } \\
\text { Acceptable }\end{array}$ & $\begin{array}{c}\text { Highly } \\
\text { Acceptable }\end{array}$ & 65.25 & 100.00 & 100.00 & 0.93 & 0.85 & 0.83 \\
\hline 500 & $\begin{array}{c}\text { Highly } \\
\text { Acceptable }\end{array}$ & $\begin{array}{c}\text { Highly } \\
\text { Acceptable }\end{array}$ & $\begin{array}{c}\text { Highly } \\
\text { Acceptable }\end{array}$ & 70.00 & 100.00 & 100.00 & 0.9 & 0.86 & 0.82 \\
\hline 750 & $\begin{array}{c}\text { Highly } \\
\text { Acceptable }\end{array}$ & $\begin{array}{c}\text { Highly } \\
\text { Acceptable }\end{array}$ & $\begin{array}{c}\text { Highly } \\
\text { Acceptable }\end{array}$ & 75.50 & 100.00 & 100.00 & 0.86 & 0.84 & 0.80 \\
\hline 1000 & $\begin{array}{c}\text { Highly } \\
\text { Acceptable }\end{array}$ & $\begin{array}{c}\text { Highly } \\
\text { Acceptable }\end{array}$ & $\begin{array}{c}\text { Highly } \\
\text { Acceptable }\end{array}$ & 100.00 & 100.00 & 100.00 & 0.98 & 0.88 & 0.84 \\
\hline 1250 & $\begin{array}{c}\text { Less } \\
\text { Acceptable }\end{array}$ & $\begin{array}{c}\text { Less } \\
\text { Acceptable }\end{array}$ & $\begin{array}{c}\text { Less } \\
\text { Acceptable }\end{array}$ & 100.00 & 100.00 & 100.00 & 0.87 & 0.83 & 0.81 \\
\hline Control & $\begin{array}{c}\text { Non- } \\
\text { Acceptable }\end{array}$ & $\begin{array}{c}\text { Non- } \\
\text { Acceptable }\end{array}$ & $\begin{array}{c}\text { Non- } \\
\text { acceptable }\end{array}$ & 20.50 & 50.65 & 78.35 & 0.84 & 0.81 & 0.76 \\
\hline $\mathrm{CD}(5 \%)$ & - & - & - & 1.99 & 1.51 & 1.47 & 0.05 & NS & 0.04 \\
\hline
\end{tabular}

Table 3. Effect of different treatments of ethrel on moisture loss, decay and PLW of Amrapali mango.

\begin{tabular}{|c|c|c|c|c|c|c|c|c|c|}
\hline \multirow{2}{*}{$\begin{array}{l}\text { Ethrel } \\
\text { (ppm) }\end{array}$} & \multicolumn{3}{|c|}{ Moisture loss(\%) } & \multicolumn{3}{|c|}{ Decay(\%) } & \multicolumn{3}{|c|}{ PLW(\%) } \\
\hline & $5^{\text {th }}$ day & $8^{\text {th }}$ day & $11^{\text {th }}$ day & $5^{\text {th }}$ day & $8^{\text {th }}$ day & $11^{\text {th }}$ day & $\overline{5^{\text {th }} \text { day }}$ & $8^{\text {th }}$ day & $11^{\text {th }}$ day \\
\hline 250 & 5.28 & 8.53 & 12.50 & 0 & 0 & 3.50 & 7.00 & 10.50 & 14.50 \\
\hline 500 & 5.53 & 9.60 & 13.50 & 0 & 0 & 4.83 & 8.50 & 11.50 & 15.50 \\
\hline 750 & 6.45 & 10.22 & 14.45 & 0 & 0.28 & 6.50 & 10.45 & 12.65 & 17.75 \\
\hline 1000 & 3.50 & 6.50 & 8.50 & 0 & 0 & 1.00 & 6.00 & 8.50 & 12.50 \\
\hline 1250 & 7.22 & 10.65 & 14.83 & 0 & 0.32 & 7.50 & 11.50 & 14.50 & 19.00 \\
\hline control & 9.50 & 14.75 & 20.81 & 0 & 3.50 & 13.75 & 4.00 & 6.00 & 10.50 \\
\hline $\mathrm{CD}(5 \%)$ & 1.22 & 1.39 & 1.32 & - & 0.368 & 1.302 & 2.20 & 1.83 & 2.19 \\
\hline
\end{tabular}

which was affected by carbon-di-oxide and lowered rate of oxygen in fruit affect the ethylene concentration. Similar results were also reported by Singh and Mandal (2000).

Data presented in Table 2 revealed that the effects of various ethrel treatments on marketability of mango fruits were significantly higher as compared to control. All ethrel treatments except $1250 \mathrm{ppm}$ at $11^{\text {th }}$ day of storage were significantly superior in improving the marketability of fruit with excellent acceptability at all the days of storage as compared to control where poor acceptability was noticed on all days of storage. The fruit treated with $1250 \mathrm{ppm}$ ethrel are over ripened at $11^{\text {th }}$ day of storage and hence its marketability is less acceptable. The marketability of fruits depends upon the appropriate production of ethylene inside fruits, optimum concentration of ethrel responsible for uniform ripening of fruit surface. If the concentration of ethrel was higher it caused rapid metabolic activi- ties, resulting in over ripening. These findings are in close conformity with the earlier results reported by Dhemre and Waskar (2003) and Madhvi et al. (2005).

Effect on ripening :Present investigation (Table 2) revealed that ethrel application enhanced the onset of ripening in mango and the response varied according to the concentration. $100 \%$ ripening was found when the fruits were treated with ethrel@1000 ppm from $5^{\text {th }}$ to $8^{\text {th }}$ days of storage. Although it was found that increase in ethrel concentration hastened the ripening process as compared to control. Similarly increase application of ethrel enhanced the ripening as reported by Singh et al. (2012) in Papaya and Siddiqui and Dhua (2009) in mango. All the fruits were ripened at $8^{\text {th }}$ days of storage except control.The mode of action of ethylene on ripening of fruits is not clearly understood. However it was explained by Holl (1977) that ethylene probably brings about the climacteric, since in many fruits the rise in respiration is directly preceded 
Table 4. Effect of different treatments of ethrel on fruit firmness, TSS, acidity and sugars of Amrapali mango.

\begin{tabular}{|c|c|c|c|c|c|c|c|c|c|c|c|c|}
\hline \multirow{2}{*}{$\begin{array}{l}\text { Ethrel } \\
\text { (ppm) }\end{array}$} & \multicolumn{3}{|c|}{ Fruit firmness (lb) } & \multicolumn{3}{|c|}{ TSS ('Brix) } & \multicolumn{3}{|c|}{ Acidity(\%) } & \multicolumn{3}{|c|}{ Sugars(\%) } \\
\hline & $\begin{array}{l}5^{\text {th }} \\
\text { day }\end{array}$ & $\begin{array}{c}8^{\text {th }} \\
\text { day }\end{array}$ & $\begin{array}{l}11^{\text {th }} \\
\text { day }\end{array}$ & $\begin{array}{c}5^{\text {th }} \\
\text { day }\end{array}$ & $\begin{array}{c}8^{\text {th }} \\
\text { day }\end{array}$ & $\begin{array}{l}11^{\text {th }} \\
\text { day }\end{array}$ & $\begin{array}{c}5^{\text {th }} \\
\text { day }\end{array}$ & $\begin{array}{c}\mathbf{8}^{\text {th }} \\
\text { day }\end{array}$ & $\begin{array}{l}11^{\text {th }} \\
\text { day }\end{array}$ & $\begin{array}{c}5^{\text {th }} \\
\text { day }\end{array}$ & $\begin{array}{c}8^{\text {th }} \\
\text { day }\end{array}$ & $\begin{array}{l}1^{\text {th }} \\
\text { day }\end{array}$ \\
\hline 250 & 22.50 & 18.25 & 13.00 & 19.00 & 20.50 & 18.50 & 0.70 & 0.45 & 0.22 & 13.50 & 15.50 & 11.25 \\
\hline 500 & 20.45 & 16.12 & 11.21 & 20.50 & 21.50 & 19.50 & 0.64 & 0.35 & 0.18 & 15.00 & 17.75 & 13.41 \\
\hline 750 & 18.52 & 14.20 & 9.20 & 21.60 & 23.53 & 20.25 & 0.59 & 0.30 & 0.17 & 17.60 & 20.57 & 15.25 \\
\hline 1000 & 16.20 & 11.00 & 7.00 & 23.50 & 26.65 & 23.00 & 0.45 & 0.23 & 0.12 & 22.25 & 24.50 & 20.65 \\
\hline 1250 & 14.50 & 9.50 & 5.45 & 22.50 & 24.52 & 21.65 & 0.52 & 0.28 & 0.15 & 19.15 & 22.10 & 17.00 \\
\hline Control & 26.55 & 22.45 & 18.51 & 18.35 & 20.00 & 17.50 & 0.80 & 0.65 & 0.35 & 11.15 & 13.50 & 10.50 \\
\hline $\mathrm{CD}(5 \%)$ & 1.65 & 1.95 & 1.75 & 1.67 & 2.16 & 2.18 & 0.10 & 0.04 & 0.04 & 2.73 & 3.28 & 2.76 \\
\hline
\end{tabular}

by an elevation in the ethylene concentration. This respiratory climacteric can be induced by ethylene treatment without a simultaneous change in tissue permeability. It has also been reported that ethylene alters the proportion of individual transfer RNA species. This effect of ethylene may influence the transfer of mRNA and thus initiate ripening. Kulkarni et al. (2011) also noted that ethrel@500 ppm induced uniform ripening without impairing taste and flavour of banana. Similarly, Mahajan et al. (2010) observed that treatment of bananas with ethylene gas (100 ppm) or ethephon (500 ppm) resulted in adequate ripening of fruits after 4 days with uniform colour, pleasant flavour, desirable firmness and acceptable quality and better shelf-life. The role of ethylene in hastening ripening of fruit is evident because it binds to receptor forming an activated complex which leads to a wide variety of physiological responses including ripening (Yang, 1980). Similarly, uniform ripening with ethrel treatment in mango was reported by Das et al. $(2011,2013)$.

Effect on specific gravity: Data presented in Table 2 showed that the specific gravity of fruits under different treatments was found statistically significant during all stages of observations except at $8^{\text {th }}$ day of storage. The maximum specific gravity of 0.98 was recorded on $5^{\text {th }}$ day with treatment of fruits treated with $1000 \mathrm{ppm}$ ethrel while minimum (0.76) was recorded on $11^{\text {th }}$ day in control. Similarly Singh et al. (2012) reported that the ethrel treated mango fruits has maximum specific gravity as compared to control at $8-10^{\text {th }}$ days of storage.

Effect on moisture loss: The significant differences were recorded among all the treatments in respect of moisture loss of fruit during storage. The minimum $(3.5,6.5$ and $8.5 \%)$ moisture loss was noticed on $5^{\text {th }}, 8^{\text {th }}$ and $11^{\text {th }}$ day of storage, respectively under fruit treated with with $1000 \mathrm{ppm}$ ethrel, while maximum loss of moisture percent $(9.5,14.75$ and $20.81 \%)$ was noticed under control at all days of storage (Table3). It might be due to moisture loss percent gradually increased with advanced period of storage (Kulkarni et al., 2004; Singh et al., 2012). The decrease in fruit moisture during storage resulted in decrease in fruit weight.

Effect on decay: The data indicated in Table 3 that no decay percent was recorded on $5^{\text {th }}$ day of storage. While all treatments were found significantly better than control. No decay was noticed in fruits treated with ethrel 250,500 and $1000 \mathrm{ppm}$ at $8^{\text {th }}$ day of storage as compared to control. It was also noticed that there was minimum decay (1\%)was observed with ethrel $1000 \mathrm{ppm}$ at $11^{\text {th }}$ day of storage as compared to other treatments. Hence, ethrel treated fruits were less prone to decay as compared to control. Similar observation was also reported by Singh et al. (2012) in ethrel treated mangoes. Effect on physiological loss in weight (PLW): It was observed from the Table 3 that the physiological loss in weight was significantly increased with the increase of ethrel concentrations. The maximum weight loss $(19.0 \%)$ was observed at $1250 \mathrm{ppm}$ where as it was only $10.5 \%$ in control at $11^{\text {th }}$ days of storage. Similarly the the loss in weight of fruit during storage both at ambient and in cold room increased with the enhancement of storage days in was also observed in pear (Dhillon and Mahajan, 2011) and papaya (Singh et al., 2012).Continuous processes of respiration and transpiration have resulted in weight loss. The loss in weight during the present investigation was more in the treated fruits than control and it increased with increase in the concentration of ethrel. The weight loss may be attributed to the physiological loss in weight due to respiration, surface evaporation through peel tissues and other biological processes taking place in both ethrel treated and untreated fruits. Siddiqui and Dhua (2009) reported that the increase in weight loss was caused due to higher rate of respiration resulting in greater utilization of stored energy during climacteric rise and enhances the degradative processes. These findings are in full agreements with Kumar and Dhawan (1995) who observed loss of weight in different 
mango varieties with ethrel treatments.

Mahajan et al. (2010) also reported that the increase in weight loss during ripening of banana fruits by ethephon or ethylene application may be due to upsurge in respiration rate of the fruit. Mahajan et al. (2008) reported an increased weight loss in guava fruits during ripening process caused by ethylene application.

Effect on fruit firmness: Fruit firmness decreased with increase in ethrel concentration and also decreased with days of storage. The maximum fruit firmness was observed in control and minimum in $1250 \mathrm{ppm}$ ethrel (Table 4). In respect of firmness of fruits, the results revealed that it decreased with the ripening of the fruits. Similar results were also obtained by Yashoda et al. (2006) and Siddqui and Dhua (2009).

Firmness is one of the most crucial factors in determining the post-harvest quality of fruits. The decrease in firmness, during ripening may be due to breakdown of insoluble protopectin into soluble pectin or by cellular disintegration leading to membrane permeability (Brinston et al., 1988).

It was reported that post-harvest treatment with ethrel promoted ripening of mango fruits, and the treated fruits were less firm than the treated ones (Mohamed Nour and Abu Goukh, 2010). A similar drop in flesh firmness was reported in guava (Bashir and $\mathrm{Abu}$ Goukh, 2003; Abu Goukh and Bashir, 2003) and mango (Venkatesan and Tamilmani, 2010).

Decreasing fruit firmness might be associated with fruit softening which is coincide with the report of Ali et al. (2011). In ripening mango, sharp physiochemical changes that occur are softening of the fruit, change in odour and flavour, increase in sugar content, reduction in organic acids, and formation of pigments, especially carotenoids (Ulrich, 1970). The fruit firmness were decreased during the ripening period in the treated than in control fruits in mango (Venkatesan and Tamilmani, 2013).Siddiqui and Dhua (2009) reported that in respect of firmness of fruits, the results revealed that it decreased with the ripening of the fruit of ethrel treated mangoes.

In general, the fruit firmness was lower under all the ethephon treatments as compared to control (Dhillon and Mahajan, 2011). The softening of flesh could be due to the degradation of soluble pectin by high activity of endopolyglacturonase in fruits (Martin-Cabrejas et al., 1994). The change in fruit firmness was also attributed to change in the turgor of the cells and changes in the composition of cell wall pectin's and lipoprotein membrane bordering the cells (Chen et al., 1981). The cortical tissues associated with swelling of parenchyma cell walls and dissolution of pectin polysaccharides were responsible for decrease in fruit firmness during ripening (Martin-Cabrejas et al., 1994).
Effect on total soluble solids (TSS): The maximum TSS $\left(26.65^{\circ}\right.$ Brix $)$ was observed in $1000 \mathrm{ppm} 8^{\text {th }}$ days of the storage as compared to other treatments and after $8^{\text {th }}$ day of storage it was gradual decreased in all the treatments (Table4). Similarly, increased total soluble solids due to post- harvest application of ethrel was also reported by Dhillon and Mahajan(2011) in pear, Singh et al.(2012) in papaya, Singh et al. (2012) in mango and Das et al. $(2011,2013)$ in mangoes. A much reduced TSS was noted after $8^{\text {th }}$ days after storage. The initial increased rate of TSS might be due to rapid loss of water from the fruits and the conversion of starch in to sugar at a faster rate (Pool et al., 1972). The decreased TSS content at later stage of storage might be due to exhaustion of substrate of conversion i.e. starch (Leopold, 1964).

Similarly Mahajan et al. (2010) reported in Banana fruit that the TSS content of fruits increased during ripening irrespective of treatments. The TSS content of banana were maximum with ethephon $1000 \mathrm{ppm}$ and lowest in control fruits. The increase in TSS during ripening may result from an increase in concentration of organic solutes as a consequence of water loss (Ryall and Pentzer, 1982). The increase may also be possible due to numerous anabolic and catabolic processes taking place in the fruit preparing it for senescence (Smith et al., 1979). Kulkarni et al. (2004) reported an increase in TSS and sugars in mango fruits treated with ethrel.

Post-harvest treatments with ethylene or ethrel were reported to induce fruit ripening and increased TSS in oranges (El Rayes, 2000) and mangoes (Siddiqui and Dhua, 2009; Mohamed Nour and Abu-Goukh, 2010; Venkatesan and Tamilmani, 2013). The increase in TSS during ripening might be due to the alteration or transformation in cell wall structure and break down of complex carbohydrates, pectic substances, hemicellulose or other polysaccharide into simple sugars and dehydration of fruits during storage (Kittur et al., 2001). Different works have been carried out to show the increase in TSS contents during ripening with ethrel treatment by Souza et al. (2006) and Yashoda et al. (2006).

Effect on acidity: It is observed from the present finding (Table 4) that acidity of the mango fruit was decreased by post harvest application of ethrel and the response varied within the concentrations. Maximum decrease $(0.12 \%)$ in total acidity was found in fruits treated with $1000 \mathrm{ppm}$ ethrel at $11^{\text {th }}$ day of the storage treatment. Similar finding was also noted in mango (Singh et al., 2012; Venkatesan and Tamilmani, 2013; Das et al. 2011, 2013) and papaya (Singh et al., 2012). The result indicates that the acidity content declined significantly with the increase in days of storage. The more acidity content was recorded in all treatments on 5 th day of storage, while it decreased markedly on $8^{\text {th }}$ and $11^{\text {th }}$ day of storage respectively. Riberau-Gayon 
(1968) suggested that transformation of organic acids into sugars was one of the reasons for decreasing organic acids during fruit ripening. Therefore, another possibility seemed that ethrel might enhance the conversion of organic acids to sugars. Present findings revealed that sugar content was increased and acidity was decreased following ethrel application. This decrease in fruit acidity might be due to the utilization of available organic acids at a faster rate in the respiration during ripening. This process might have been triggered with the exogenous application of ethephon. The conversion of organic acids into soluble sugars and long chain polysaccharides may also leads to decrease in acids (Lelievre et al., 1997). Similar results were also reported by Mahajan et al. (2008) in guava, Siddiqui and Dhua (2009), Dhillon and Mahajan (2011) in pear in mango who recorded a decrease in acid content during ripening and storage.

Titratable acidity of fresh fruits tended to decrease at each stage of harvest as maturity progressed. The decline in acidity on ripening which may accompany the ripening of fruits appear to result, at least in part, from the conversion of acids into sugars and their derivatives and their further utilization in metabolic process i.e. respiration in the fruit. These results coincide with those Srinivasa et al. (2002) and Yashoda et al. (2006) .The increase in organoleptic rating mainly associated with improvement in fruit color, increase in TSS, decrease in acidity and fruit firmness. The organoleptic score is the balance between sugars and acids.

Effect on sugars: The present investigation revealed that the sugar content increased with increasing ethrel concentration (Table 4). The maximum sugar content $(24.5 \%)$ was observed in $1000 \mathrm{ppm}$ treated fruits at $8^{\text {th }}$ days of storage. The values of sugar content increased upto 8 days after storage and proved to be significantly better treatment and declined thereafter. In the present experiment, ethrel enhanced the rate of accumulation of reducing sugar in mango fruits. Similarly, high percentage of sugar with ethrel application was observed by Singh et al. (2012) in mango and Singh et al. (2012) in papaya. It was due to faster rate of respiration and formation of sugar content with oxidation of carbohydrate. The finding is collaborated with the result of Kumar and Singh (1993) who observed that higher percent age of sugar in ethrel treated mango fruits over control. Similarly, the increase in sugar content during storage in ethrel treated mango (Siddiqui and Dhua, 2009) and pear fruits (Dhillon and Mahajan, 2011).

The levels of sugar increased with the advancement of storage period up to $8^{\text {th }}$ day with gradual ripening. These findings are in full agreements with findings of Gowda and Huddar (2001) and Yashoda et al. (2006). The changes in total sugar contents during ripening are very much related with TSS. An increase in total sugar contents was probably due to starch and polysaccharides in to soluble sugars and dehydration of fruits. In our experiment, the ethrel treated fruits had more total sugar contents than that of control. These results are in line with Kulkarni et al. (2004) who reported same results with different varieties of mango. The decline in total sugar after attaining the peak might be due to its faster utilization in respiration when the fruits were over ripe (Hoda et al., 2001). The increase in soluble solids and sugars upon ripening could be due to hydrolysis of starch and organic compounds ( Lelievre et al., 1997).

Under Punjab conditions, Amrapali mango is late ripened as compared to other varieties of mango. To overcome the problem of late and uneven ripening, the present study was undertaken. Because, there was no any report is available regarding the artificial ripening of Amrapali mango with ethrel treatment under Punjab conditions. Hence in the present study, it was found that Amrapali mangoes harvested at mature green stage treated with $1000 \mathrm{ppm}$ ethrel solution for five minutes are ripened evenly and found best in term of quality characteristics during storage at room temperature.

\section{Conclusion}

The excellent flavour with deep yellow fruit colour, organoleptic taste and highly acceptable marketability was observed at $1000 \mathrm{ppm}$ ethrel treatment at $11^{\text {th }}$ day of storage as compared to the other treatments. Fruit ripening $(100 \%)$, specific gravity $(0.84)$, TSS $\left(23^{\circ}\right.$ Brix) and sugars $(20.65 \%)$ were highest in the fruits treated with $1000 \mathrm{ppm}$ ethrel treatment at $11^{\text {th }}$ day of storage as compared to the rest of treatments. Lowest moisture loss $(8.5 \%)$, decay (1\%), PLW (12.50\%) and acidity $(0.12 \%)$ were observed in the fruits treated with $1000 \mathrm{ppm}$ of ethrel as compared to other treatments at $11^{\text {th }}$ day of storage. It was concluded that the physiological matured mango cultivar Amrapali treated with $1000 \mathrm{ppm}$ of ethrel for five minutes and ripened and stored at room temperature exhibited best post-harvest quality attributes during storage period.

\section{REFERENCES}

Abu-Goukh, A. A. and Bashir, H. A. (2003). Changes in pectic enzymes and cellulase activity during guava fruit ripening. Journal of Food Chemistry, 83(2): 213-218

Ali, A., Muhammad, M.T.M., Sijam, K. And Siddiqui, Y. (2011). Effect of Chitosan coatings on the physiochemical characteristics of Eksotika II Papaya(Carica papaya L.) fruit during cold storage. Food Chemistry, 124(2): 620-626

Amerine, M.A., Pangborn, R.M. and Rossessler, E.B. (1965). Principles of sensory evaluation of food. Acadamic Press inc., NewYork USA. pp.366-374

Anonymous .(2014). Indian Horticulture Data Base, National Horticulture Board (NHB), Gurgaon, Haryana (India).

Bashir, H. A. and Abu-Goukh, A.A. (2003). Compositional 
changes during guava fruit ripening. Journal of Food Chemistry .80(4): 213-218

Brackmann, A., Strief, J. and Bangerth, F. (1993). Relationship between reduced aroma production and lipid metabolism of apple during storage. Journal of American Society for Horticultural Science. 118(2) : 243-247

Brinston, K., Dey, P.M., John, M.A., Pridhan, J.B .(1988). Post-harvest changes in Mangifera indica mesocarp walls and cytoplasmic polysaccharides. Phytochemistry. 27:719-723

Chattopadhaya, T.K. and Mango, A.(1996). Text book on pomology, Kalyani Publishers, India. pp. 1- 37

Chen, P.M., Spotts, R.A. and Mellenthin, W.M . (1981). Stem end decay and quality of low oxygen stored d' Anjou pears. Journal of American Society for Horticultural Science, 106(6): 695-698

Das S.C., Balamohan T.N., Auxcilia J. and Nalina L. (2011). Early and uniform ripening of mango cv. Alphonso with ethrel treatment. The Asian Journal of Horticulture, 6 (1): $185-90$

Das, S.C. and Balamohan, T.N. (2013). Early and uniform ripening of mango with ethrel treatment cv. Sendura The Asian Journal of Horticulture. 8(1) : 336-341

Dhemre, J.K. and Waskar, D.P. (2003).Effect of post-harvest treatments on shelf life and quality of Kesar mango fruit during storage. Journal of Maharastra Agricultural University, $23: 159-163$

Dhillon, W.S. and Mahajan. B.V.C. (2011). Ethylene and ethephon induced fruit ripening in pear. Journal of Stored Products and Postharvest Research, 2(3): 45-51

El Rayes, D.A. (2000). Enhancement of colour development and fruit ripening of 'Washington Navel'and 'Amoon'oranges by ethrel pre-harvest application. Assiut Journal of Agricultural Sciences, 31(2): 71-87

Gomez, K.A. and Gomez.,A.K. (1984). Statistical Procedures for Agricultural Research. 2nd ed. John Wiley \& Sons. New York. pp. 207-215

Gowda, I.N.D. and Huddar, A.G. (2001). Studies on ripening changes in mango (Mangifera indica L.) fruits. Journal of Food Science and Technology, 38(2): 135-137

Hiwale, S.S. and Singh, S.P.(2003). Prolonging shelf-life of guava. Indian Journal of Horticulture, 60(1): 1-9

Hoda, M.N., Yadav, G.S., Singh, S. and Singh, J. (2001). Storage behaviour of mango hybrids. Indian Journal of Agricultural Sciences, 71(7): 469-472

Holl,W.(1977). Fruit ripening. Plant Research and Development, 5:117-126

Kader, A. and Mitcham, B. (2008). Optimum Procedures for Ripening Mangoes. In: Fruit Ripening and Ethylene Management: 47-48. Univ. Calif. Postharvest Technology Research and Information Center Publication Series \#9:http://postharvest.ucdavis.edu/Pubs/Pub Desc 9.pdf.

Kittur, F.S., Saroja, N. and Tharanathan, R.N . (2001). Polysaccharide-based composite coating formulations for shelf-life extension of fresh banana and mango. European Food Research and Technology, 213(4-5): 306-311

Kulkarni, S.G., Kudachikar, V.B. and Keshava Prakash, M.N .(2011). Studies on physico-chemical changes during artificial ripening of banana (Musa sp) variety 'Robusta'. Journal of Food Science and Technology. 48(6): 730-734

Kulkarni, S.G., Kudachikar, V.B., Vasanta, M.S., Prakash, M.N.K., Prasad, B.A. and Ramana, K.V.R . (2004).
Studies on effect of ethrel dip treatment on ripening behaviour of mango variety Neelum. Mysore Journal of Food Science and Technology, 41:216-220

Kumar, A. and Dhawan, S. S .(1995). Effect of post-harvest treatments on the enhancement of ripening of mango (Mangifera indica L) fruit cv. Dashehari. Haryana Journal of Horticultural Sciences, 24(2): 109-115

Kumar, P. and Singh, S. (1993). Effect of $\mathrm{GA}_{3}$ and ethrel on ripening and quality of mango cv. Amrapali. The Horticulture Journal, 6(1):19-23.

Lalel, H.J.D., Singh, Z. and Tan, S.C.(2003). Maturity stage at harvest affects fruit ripening, quality and biosynthesis of aroma volatile compounds in 'Kensington Pride' mango. Journal of Horticultural Science and Biotechnology .78 (2): 225-233

Lelievre, J.M., Tichit, L., Dao, P., Fillion, L., Nam, Y.W., Pech, J.L. and Latche, A. (1997). Effects of chilling on the expression of ethylene biosynthetic gene in 'Passecrassane' pears (Pyrus communis) fruits. Plant Molecular Biology. 33(5): 847-855

Leopold, A.C .(1964). Plant Growth and Development. Mc Graw Hill Publication.NewYork.

Madhvi, M., Srihari, D. and Dilip Babu, J. (2005). Effect of post-harvest ethrel treatment on ripening and quality of sapota cv. Pala fruits. Indian Journal of Horticulture, 62 (2): 187-189

Mahajan, B.V.C., Tajender, K., Gill, M.I.S., Dhaliwal, H.S., Ghuman, B.S. and Chahil, B. S.(2010). Studies on optimization of ripening techniques for banana. Journal of Food Science and Technology, 47(3): 315-319

Mahajan, B.V.C., Singh, G., Dhatt, A.S .(2008). Studies on ripening behaviour and quality of winter guava with ethylene gas ethephon treatments. Journal of Food Science and Technology, 45:81-84

Martin Cabrejas, M.A., Waldran, K.W., Selvendaran, R.R., Parket, M.L. and Maotes, G.K.(1994). Ripening related changes in cell wall of 'Spanish' pear. Physiologia Plantarum, 91(4): 671-679

Mohamed, H. E. and Abu-Goukh, A. A. (2003). Effect of ethrel in aqueous solution and ethylene released from ethrel on mango fruit ripening. Journal of Horticultural Science and Biotechnology, 78(4): 568-573

Mohamed-Nour, I.A. and Abu-Goukh, A.B.A. (2010) . Effect of ethrel in aqueous solution and ethylene released from ethrel on guava fruit ripening. Agriculture and Biology Journal of North America, 1(3): 232-237

Montalvo, E., Garcia, H.S., Tovar, B. and Mata, M. (2007). Application of exogenous ethylene on postharvest ripening of refrigerated Ataulfo mangoes. Food Science and Technology, 40: 1466-1472

Pool, R.M., Weaver, R.J. and Kliever, W.M. (1972). The effect of growth regulators on change in fruits of Thompson seedless during cold storage. Journal of American Society for Horticultural Science, 97: 67-70

Ribereau Gayon, G. (1968). Etudedes mechanisms synthese at de transformation delacide mailique,de l' acide tartique at de I'acide mailique,chaz Vitis vinifera L. Phytochemistry, 7:1471-1482

Reyes, M.U. and Paul, R.F. (1995). Effect of storage temperature and ethylene treatment on guava fruit ripening. Postharvest Biology and Technology, 6: 357

Ryall, A.L. and Pentzer, W.T. (1982). Handling, transportation and storage of fruits and vegetables. Vol. 2, AVI 
Publ Co, Westport, Connecticut, pp 1-40

Sharma, D.K., Singh, R.N. and Mazumdar, P.K.(1981). Fruit quality of mango cultivars. National Symposium on tropical and subtropical fruit crop, Bangalore. pp 4.

Siddiqui, M.W. and Dhua, R.S. (2009).Stanadization of ethrel treatment for inducing ripening of mango var. "Himsagar". Proceeding of International Conference on Horticulture, November9-12, Begalore: 1641-1648

Singh, Z. and Janes, J .(2001). Effect of post-harvest application of ethephon on fruit ripening, quality and shelflife of mango under modified atmosphere packaging. Acta Horticulturae, 533: 599-602

Singh, J.P. and Mandal, B.K.(2000). Role of wrapper and post-harvest application of $\mathrm{CaNO}_{3}$ on the storage behaviour of sub-tropical litchi cv. Manaraji. Journal of Applied Biology, 10(1): 37- 42

Singh, P., Kumar, S. and Maji, S. (2012). Effect of ethrel on post harvest changes in papaya(Carica papaya L.) fruits. Hort Flora Research Spectrum, 1(3): 225-230

Singh, P., Singh, M.K., Kumar, V., Kumar, M., Malik, S. (2012). Effect of physico-chemical treatments on ripening behaviour and post-harvest quality of Amrapali mango (Mangifera indica L.) during storage. Journal of Environmental Biology, 33: 227-232

Smith, R.B., Lougheed, E.C., Franklin, E.W., McMillan, I . (1979). The starch iodine test for determining stage of maturation in apples. Canadian Journal of Plant Science, 59(3):725-735

Souza, B.S., Durigan, J.F., Donadon, J.R. and Souza, P.S. (2006). Fresh mangos ripened naturally or induced by ethylene and stored in different packages. RevistaBrasileira-de-Fruticultura, 28(2): 271-275

Srinivasa, P.C., Baskaran, R., Ramesh, M.N., Prashanth, K.V.H. and Tharanathan, R.N .(2002). Storage studies of mango packed using bio-degradable chitosan film. European Food Research and Technology, 215(6): 504 $-508$

Ulrich, R. (1970). In: Organic acids. A.C. Hulme (ed.), "The Biochemistry of fruits and their products", Academic Press, London, 1, 89-118

Venkatasubbaiah, K., Jagadeesh, S.L., Thammaiah, N. and Chavan, M.L. (2013). Changes in physico-chemical and sensory characteristics of banana fruit cv. Grand Naine. Karnataka Journal of Agricultural Sciences, 26(1):111114

Venkatesan,T. and Tamilmani,C.(2010).Effect of ethrel on softening of off-season fruits of mango ( Mangifera indica L. var. Neelum) during ripening. Current Botany, 1(1):29-33

Venkatesan, T. and Tamilmani, C.(2013). Effect of ethrel on the physiochemical changes of off-season fruits of mango (Mangifera indica L. var. Neelum) during ripening. International Journal of Agricultural and Food Science, 3(4): 171-175

Yang, SF.(1980). Regulation of ethylene biosynthesis. Hort Science, 15:238-243

Yashoda, H.M., Prabha, T.N. and Tharanathan, R.N . (2006). Mango ripening: changes in cell wall constituents in relation to textural softening. Journal of the Science Food and Agriculture, 86(5): 713-721 